\title{
Trends in the international news coverage on Latin America in Germany in the 21 st century $^{1}$
}

\author{
Regina Cazzamatta' \\ https://orcid.org/0000-0002-7162-3219 \\ I - Universität Erfurt \\ Erfurt, Turíngia, Alemanha
}

Abstract: This study aims at analysing the main developments in foreign reporting of Latin America by the German press. The paper provides a content analysis of 3.831 articles published in quality German publications (SZ, FAZ, Der Spiegel, and taz) between 2000 and 2014. The most common news factors related to the continent are found to be "magnitude," "power status," "economic proximity", and "personification." Additionally, we identified a decrease in hard news over the years ( 6 pp within Politics and 8 pp amidst Economy). Despite depoliticisation, a tendency towards tabloidisation was not confirmed since factors such as personification and crisis remained constant.

Keywords: news values; Latin America's foreign reporting; global reporting; international communication; German press.

Resumo: Tendências na cobertura internacional da América Latina na Alemanha no início do século 21 - Este estudo tem como objetivo analisar as principais tendências da cobertura internacional da América Latina pela imprensa alemã. $O$ artigo fornece uma análise de conteúdo de 3.831 matérias publicadas em prestigiados periódicos alemães (SZ, FAZ, Der Spiegel e taz) entre 2000 e 2014. Os fatores noticiosos mais comuns relacionados ao continente são "magnitude", "status de poder", "proximidade econômica" e "personificação". Além disso, identificamos uma diminuição de "hard news" ao longo dos anos (6 pp na área política e 8 pp na econômica). Apesar da despolitização, uma tendência à tabloidização não foi confirmada, pois fatores como personificação e crise permaneceram constantes.

Palavras-chave: valores noticiosos; cobertura latino americana; reportagens internacionais; comunicação global; imprensa alemã.

\footnotetext{
1 This research received financial support from CNPq (DAAD/290017/2014-9).
} 


\section{Introduction}

This study aims at exploring the trends of Latin America's foreign reporting by German quality press during the first fifteen years of the 21 st century. Not only the structures of global news but also Latin America's geopolitical order underwent considerable changes with the dawn of the new millennium. Thus, it seems plausible to reassess and update its most common news factors. A report of the Ibero-American Institute on Latin American research in Germany indicates a lack of studies regarding the continent. While there is a considerable amount of international analysis about a few Asian countries and the Islamic world, Latin American's research is insufficient and outdated (GÖBEL, BIRLE \& SPECHT, 2009).

Major geopolitical transformation, technological progress, and economic changes have had a substantial impact on the process of international newsgathering (PATERSON \& SREBERNY, 2004, p. 8). Several analyses of news flows have demonstrated an impressive, similar scheme of foreign-news reporting. The press tends to report mostly about its regional neighbours, followed by consistent newsmakers (i.e., USA and West Europe) and the "hot spots", i.e., crisis regions. One can consider other parts of the world, such as Latin America or Africa as invisible to the media map (SCHRAMM, 1959; SREBERNY-MOHAMMADI \& GRANT, 1985; TIELE, 2010; WU, 2004).

However, despite minimal press attention, Latin America has been remarkably transformed in the last 30 years (COVARRUBIAS \& DOMÍNGEUZ, 2015). Therefore, scholars tend now to describe the region as "a transformed Latin America in a rapidly changing world" (LOWENTHAL \& BARON, 2015), while discussing its "new geopolitical position" (NOLTE \& HOFFMANN, 2007). The representation of Latin America constructed by the Western media can determine the public perception not only in the North but also in the southern hemisphere because the preponderant news circulation persists to be from the North to the South and just a restricted communication between the South exists (THUSSU, 2004, p. 54).

Considering the global tendency of media tabloidisation and intense commercialisation (ESSER, 1999; SPARKS, 2000), we assume an increase in soft-news coverage and the intensification of specific news factors such as personification, crisis \& conflicts and negativity. Since Latin America is considered a blind spot in global news, we selected the German press system due to its steady development of mass-circulation newspapers (HALLIN \& MANCINI, 2004). Additionally, Europeans are also more likely to declare they read international news very carefully, especially the Germans (29\%) when compared to the UK (19\%), France and Spain, both with 16\% (PEW RESEARCH CENTER, 2018). 


\section{Theoretical background}

\section{News factors: a short literature review}

The news value approach used in our analysis comprises one among other theories of news selection and focuses on the question of how events turn into news. This research thread investigates, in general, the content characteristics of events as portrayed in mass media, i.e., what exactly makes a story newsworthy. Scholars recognise Walter Lippman (1998 [1922]) as the pioneer of the field, given how he discussed, still in a basic form, aspects such as sensationalism, proximity, relevance or facticity (ibid.). Östgaard (1965) identified three elements - simplification, identification, and sensationalism - which impact the news flow. The research area further developed with the news factor catalogue of Galtung and Ruge (1965), the most cited work that constituted a starting point for many other empirical analyses since the 60s. The factors proposed by the authors were, in their words, "nothing but common-sense perception psychology" (GALTUNG \& RUGE, 1965, p. 66).

Subsequently, Rosengren $(1970,1974)$ made a valuable contribution to the concept's discussions, by comparing between intra-media (coverage of the event) and extramedia data (about the "real" event). Schulz (1976), however, considered as a "radical constructivist" (HAFEZ, 2002), did not agree with Rosengren's arguments and alleged that the comparison between reality and media reality is pointless and leads to falsification since only different perspectives of realities could be evaluated (SCHULZ, 1976, p. 25). Apart from this constructivist methodological considerations, one can still consider the work from Schulz as a turning point, since the author empirically operationalised for the first time the news factors and demonstrated their factual influence on journalistic selection. Schulz enlarged and adapted Galtung and Ruge's catalogue. For instance, he discriminated between geographical, political, and cultural proximity. The author also distinguished the notions of news factor from news values. In his view, reporters attribute news value to a specific event since they convey particular news factors that correlate with their standards of choice. Hence, news value is, in his words, an indication of journalistic hypotheses of reality (ibid. 1976, p. 30).

Another research landmark is found in Staab's study (1990a; b). Particularly relevant for this paper is the author consideration of the factor "economic proximity" as well as the introduction of the discussion over a "functional model" of news selection (contrary to the "causal model"). According to this functional framework, journalists do not solely choose an occurrence due to their characteristics or news factors. They can also attribute and highlight news factors to a story in order to emphasise some happenings and topics, i.e., they instrumentalise news factors (STAAB, 1990b, p. 429). However, the assumption 
of the functional model does not disprove the causal model. Because news factors are valid measurements of journalistic news choice, they can be used to endorse the coverage of specific topics (ibid.). Thus, the author does not understand the concept of news value as a theory to explain news selection, but as a useful instrument to describe and analyse media reality. Based on this theoretical perspective, this paper aims at answering the following research questions: RQ1) What are the principal news factors associated with Latin America foreign-reporting by the German press? RQ2) What are the main trends of coverage over the last 15 years? RQ3) Is there any tendency towards tabloidisation², i.e., tabloids news values such as personification and conflict-orientation?

\section{Methodology}

\section{Unit of Analysis}

This empirical study comprises at first two national market-leading German newspapers, which possess the most significant number of correspondents based in Latin America, namely the Süddeutsche Zeitung (liberal and politically broad) and the Frankfurter Allgemeine Zeitung (economically liberal and politically conservative). The most critical weekly political magazine of the country (Der Spiegel) is also included. Aside from these long-established three periodicals, we also incorporated the alternative tageszeitung (taz) because of its role regarding the agenda-setting process in the country. The choice of publications took into consideration three crucial factors: readership strength, the effect of opinions on other journalists, and political scope. The analysed periodicals boast the leading sales-volume and the broader readership within prestigious papers in Germany (AWA, 2014; IVW, 2014). Concerning the sales amount, taz is an exception. However, it was still considered to expand the political range of analysis (NOELLE-NEUMANN, SCHULZ \& WILKE, 2002, p. 435; PÜRER \& RAABE, 2007, p. 15). Ultimately, one also sees these publications as "leading media," as explained by the "hypothesis of coordination," i.e., they influence the coverage of other media outlets as well (BROSIUS, KOSCHEL \& HAAS, 2009, p. 164).

\section{Sample}

Each contribution from the printed version of the mentioned periodicals related to twenty Latin American states ${ }^{3}$ was extracted, totalling a fifteen years corpus composed by articles published between January 2000 and December 2014. In the first stage,

2 In general, one describes tabloidisation as the extension of tabloid news values to the quality publications (LEFKOWITZ, 2018). Studies associate this tendency for instance with an increasingly apolitical, personalised and human-interest or soft-news oriented stories (GRAN, 2015; MAIER, RUHRMANN \& STENGEL, 2009)

3 Latin America is foremost a politically and culturally defined terminology, which describe the Latin languagespeaking states of South America, Central America and Mexico, in opposition to the Anglo-America. The English-speaking Caribbean islands or even Dutch-speaking countries such as Surinam are out of our scope (HOFFMANN \& NOLTE, 2008; WERZ, 2010) 
we catalogued every text in order to organise the primary unit of analysis (21.929 news items). We excluded the material from SZ.de, FAZ.NET, taz.de, and Der Spiegel Online. A study comparing newspapers and their online service amidst 18 European nations showed that $70 \%$ of the most relevant online news is frequently very similar to their printed forms (Wurff, 2008, p. 70). To ensure that each nation would have the exact probability of being selected for the empirical analysis, we drew a sample of $25 \%$ of published articles from each country.

Moreover, we ignored small articles (less than 150 words) since they comprise almost no news factors. Each $n-4$ th printed text ( $25 \%$ of the total) of a country from a publication was then selected based on the rotation concept. The requirements for a layered sampling were thus achieved, considering we knew the population distribution. The final sample has 3.831 news items. We conducted a Holsti coefficient reliability test based on a sampling of $5 \%$, and the results showed a $94.3 \%$ of correspondence between the two researchers.

\section{Notes on the Categories}

In order to provide an overview of the evolution of Latin American news reporting, every single article was coded according to country, the area of reporting, central theme, subtopics, described actors ${ }^{4}$ and evaluation of events (positive, negative or neutral). Besides the twenty countries, we added a category named "multinational coverage" for reports related to more than one nation or dealing with intraregional organisations such as Mercosur, NAFTA or UNASUR (4\% of the entire coverage). Furthermore, we analysed the presented news factor not only based on their frequency but also on their intensity from null to three (not detected at all; light, medium or strong presence), based on definitions provided by previous studies ${ }^{5}$ (HARCUP \& O'NEILL, 2017; SCHULZ, 1976; STAAB, 1990a). For better visualisation, we occasionally aggregated the development trends in three different periods - the first five (from 2000-2004), the next five (2005-2009) and the last five years of analysis (2010-2014). In general, we considered:

- Magnitude: number of affected people (no person impacted at all; individual level; social subgroups or the whole nation's involvement).

- Power Status: operationalised through GDP, military expenditure, number of scientific publications, and population size (CAZZAMATTA, 2018; HAGEN et al., 1998)

- Personification: how a person is described (no mention to people; named but without importance for the main event; the action of a person can describe the event; people are in the centre of the occurrence).

4 Official states representatives, organised social groups, non-organised social groups, and personalities from Latin America, Europe, the USA, or other nations.

5 A detailed codebook can be sent upon on request. 
- Economic proximity: operationalised through trade balance with Germany (BUNDESAMT, 2015).

- Eliteness: representation of elites, counter-elites, and non-organised social groups.

- Prominence: Degree of actors' notoriety (regional, national, or international awareness).

- Crisis and Conflict: Crisis' measurement according to the classification of the Heidelberg Conflict Research: non-violent crises, violent crises and limited wars (HIIK, 2013)

- Negativity: Evaluation of an event. It was coded separated from the previous category since crises can also be reported in a positive way (e.g., peace agreement).

- Damage and Success: the degree of harm or favourable outcomes.

\section{Results}

Similar to Staab's findings (1990a, p. 211), the individual news factors in this work, including the factor "power status," scarcely show any individual influence on the articles' length. The power status of a country is crucial for the press coverage, accurately how often a particular nation is reported and receives press attention $(r=.813, p<0.001)$, but without effect on the size of the article.

\section{Thematic development over the years}

Looking at the thematic areas of coverage, the ranking of topics throughout the analysis from 2000 to 2014 remains more or less stable. Table 1 exhibits the thematic distribution of the articles within the three periods. The foreign reporting of Latin America concentrates mostly on "Domestic and Foreign Policy," "Culture \& Society" and "Economy \& Finance," while other thematic areas have been less covered and, in general, mostly in connection with significant key events. From 2000 to 2003, "Economy \& Finance" remained consistently in the second place. The peak of attention concentrated in 2001 and 2002 due to the Argentine economic crisis. In 2004, the area of "Economy \& Finance" (13.10\%) lost importance and almost equated to "Culture \& Society" (13.90 \%). 


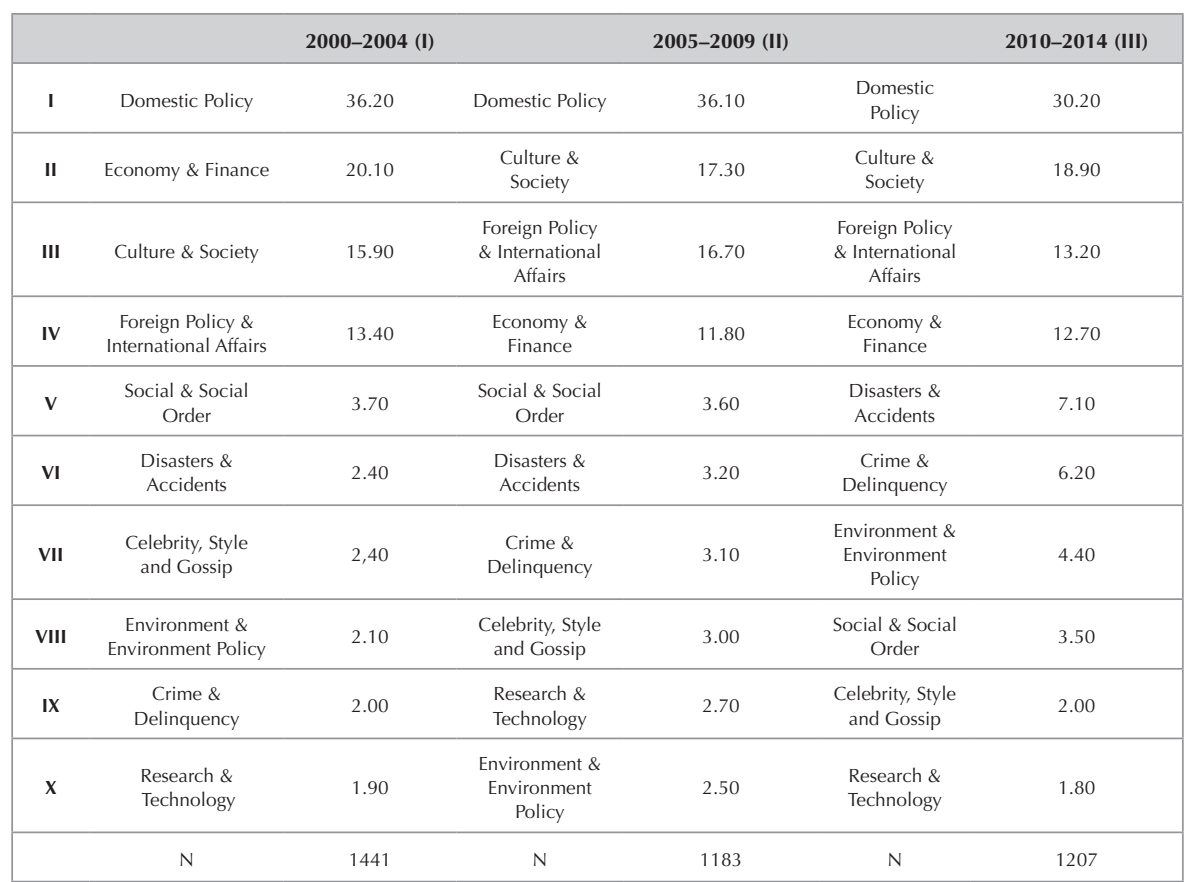

Tab.1. Development of the thematic covered areas of Latin America's foreign-reporting in three different stages of analysis (in percentage)

"Domestic Policy" has the highest importance amidst Latin America foreign reporting and has always stood in the first position. However, the area shows a decline of 6 percentage points (pp) over time. While "Domestic Policy" accounted for $36.20 \%$ of the news coverage on Latin America in the first five years, this share dropped to $30.20 \%$ in the last five years, suggesting a loss of importance or a tabloidisation trend. Observing the Latin American news coverage during these three periods, we notice a slight loss of importance of "Domestic Policy" (6 pp) and "Economy \& Finance" (8pp) in favour of non-political and non-economic thematic areas such as "Disasters \& Accidents" (increase of 5pp), "Crime \& Delinquency" (4pp), "Culture \& Society" (3pp) or "Environment \& Environment Policy" (2pp). In other words, one noticed an increasingly apolitical reporting in favour of a more human-interest orientation.

That loss of importance of the "Domestic Policy" area was noted across all analysed newspapers and magazine. The FAZ had the smallest reduction of four pp., while this decrease in the $S Z$ (9pp), taz, and Der Spiegel (both of 10pp) was significantly more substantial. After the stabilisation of the Argentine economy, an apparent reduction of the thematic area "Economy \& Finance" was also observed in the SZ (5pp) and FAZ (6pp). In the case of the taz (reduction of 2pp) and of the Der Spiegel (remains stable), this reduction 
was not as clear. Looking at "Culture \& Society" coverage area, we detected a noticeable increase for $S Z$ (7pp) and Der Spiegel (5pp), while for taz and FAZ the percentage remained more or less stable. Cultural topics are always ranked in second place in the case of taz and the fourth in FAZ. The topic's attention is different among the two newspapers, but none shows large fluctuations over the ranking of cultural topics, as seen in Table 2. On the other hand, the thematic areas of "Natural Catastrophes \& Disasters" and "Crime \& Delinquency" became more important for the entire press. Environment issues remained stable in Der Spiegel, while the other newspapers showed a slight increase.

\begin{tabular}{|c|c|c|c|}
\hline & $(2000-2004) I$ & (2005-2009) II & (2010-2014) III \\
\hline \multicolumn{4}{|l|}{ Süddeutsche Zeitung (SZ) } \\
\hline Domestic Policy & 35.50 & 32.00 & 26.50 \\
\hline Economy \& Finance & 18.70 & 7.80 & 12.70 \\
\hline Culture \& Society & 15.20 & 20.10 & 22.50 \\
\hline Foreign Policy \& International Affairs & 12.90 & 16.00 & 11.20 \\
\hline Celebrity, Style and Gossip & 4.40 & 4.10 & 3.70 \\
\hline Crime \& Delinquency & 3.60 & 3.80 & 6.90 \\
\hline Research \& Technology & 2.80 & 3.80 & 2.30 \\
\hline Social \& Social Order & 2.50 & 3.10 & 1.70 \\
\hline Disasters \& Accidents & 2.20 & 6.30 & 8.60 \\
\hline \multirow[t]{2}{*}{ Environment \& Environment Policy } & 2.20 & 3.10 & 3.70 \\
\hline & 363 & 319 & 347 \\
\hline \multicolumn{4}{|l|}{ Frankfurter Allgemeine Zeitung (FAZ) } \\
\hline Domestic Policy & 31.40 & 34.90 & 27.60 \\
\hline Economy \& Finance & 28.70 & 22.10 & 22.80 \\
\hline Foreign Policy \& International Affairs & 13.40 & 18.30 & 16.80 \\
\hline Culture \& Society & 13.20 & 11.20 & 12.00 \\
\hline Social \& Social Order & 4.60 & 4.60 & 1.20 \\
\hline Disasters \& Accidents & 3.00 & 2.00 & 7.80 \\
\hline Crime \& Delinquency & 2.00 & 2.50 & 5.40 \\
\hline Celebrity, Style, and Gossip & 1.80 & 2.30 & 1.80 \\
\hline Environment \& Environment Policy & 1.10 & 0.50 & 2.40 \\
\hline \multirow[t]{2}{*}{ Research \& Technology } & 0.90 & 1.50 & 2.10 \\
\hline & 659 & 393 & 333 \\
\hline
\end{tabular}

Tab. 2.1. Thematic areas of Latin America's foreign reporting by newspapers and period of analysis (in percentage) 


\begin{tabular}{|c|c|c|c|}
\hline & (2000-2004) I & (2005-2009) II & (2010-2014) III \\
\hline \multicolumn{4}{|l|}{ tageszeitung (taz) } \\
\hline Domestic Policy & 45.50 & 42.20 & 35.30 \\
\hline Culture \& Society & 21.90 & 21.50 & 20.90 \\
\hline Foreign Policy \& International Affairs & 12.50 & 15.60 & 12.00 \\
\hline Economy \& Finance & 8.70 & 6.90 & 6.70 \\
\hline Social \& Social Order & 4.10 & 3.30 & 6.70 \\
\hline Environment \& Environment Policy & 3.20 & 3.30 & 6.00 \\
\hline Research \& Technology & 2.00 & 1.00 & 0.40 \\
\hline Disasters \& Accidents & 1.50 & 2.00 & 5.10 \\
\hline Crime \& Delinquency & 0.30 & 2.80 & 5.80 \\
\hline \multirow[t]{2}{*}{ Celebrity, Style and Gossip } & 0.30 & 1.30 & 1.10 \\
\hline & 343 & 391 & 450 \\
\hline \multicolumn{4}{|l|}{ Der Spiegel } \\
\hline Domestic Policy & 38.20 & 28.70 & 28.60 \\
\hline Foreign Policy \& International Affairs & 19.70 & 16.30 & 13.00 \\
\hline Culture \& Society & 15.80 & 16.30 & 20.80 \\
\hline Celebrity, Style and Gossip & 6.60 & 10.00 & 0.00 \\
\hline Research \& Technology & 5.30 & 12.50 & 6.50 \\
\hline Environment \& Environment Policy & 5.30 & 6.30 & 6.50 \\
\hline Economy \& Finance & 3.90 & 1.30 & 3.90 \\
\hline Crime \& Delinquency & 2.60 & 5.00 & 9.10 \\
\hline Disasters \& Accidents & 1.30 & 2.50 & 9.10 \\
\hline Social \& Social Order & 1.30 & 1.30 & 2.60 \\
\hline $\mathbf{N}$ & 76 & 80 & 77 \\
\hline
\end{tabular}

Tab. 2.2. Thematic areas of Latin America's foreign reporting by newspapers and period of analysis (in percentage)

\section{The importance of news factors within the publications}

Based on the frequency of their occurrence, Table 3 shows the most significant and recurrent coded news factors. The German press reports most frequently about events with significant "magnitude". In other words, about events that (might) involve or have an enormous impact on large social groups or subgroups or even on all citizens of a country. The factor "power status" is also in the second position of significance in the case of the $S Z$, FAZ and Der Spiegel. Only within taz, "personification" appears more frequently than "power status." The factor "personification" stays among the four most common news factor depending on the publication. 
Furthermore, the factor "economic proximity" has a remarkable significance. That means foreign reporting about Latin America takes into account, above all, countries that have a close economic relationship with Germany, i.e., Brazil, Mexico, and Argentina. For more details about the specific coverage of particular states, see Cazzamatta (2014a; b, 2018). Eliteness also plays an important role. Based on the analysis of the total number of described actors, the press preference for elite-people or elite-groups is clear. The media reports mostly about individuals, groups or institutions that have some social power, such as "official state representatives" or "organised social groups." "Unorganised groups" and ordinary people are less likely to be reported.

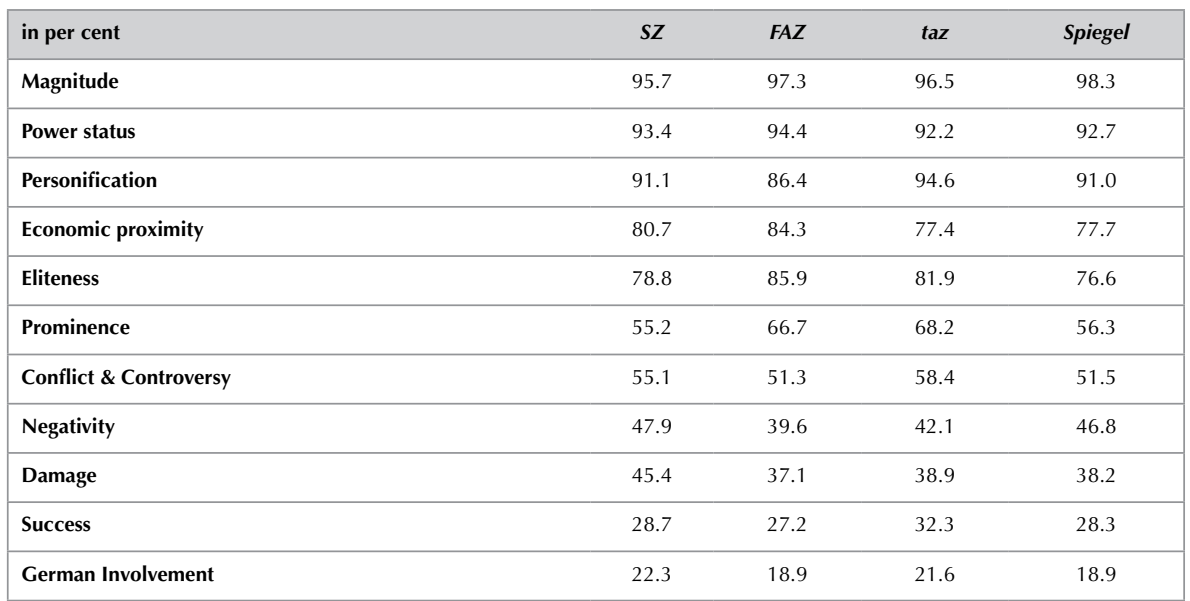

Tab. 3. The proportion of articles to which the news factors apply from 2000 to 2014

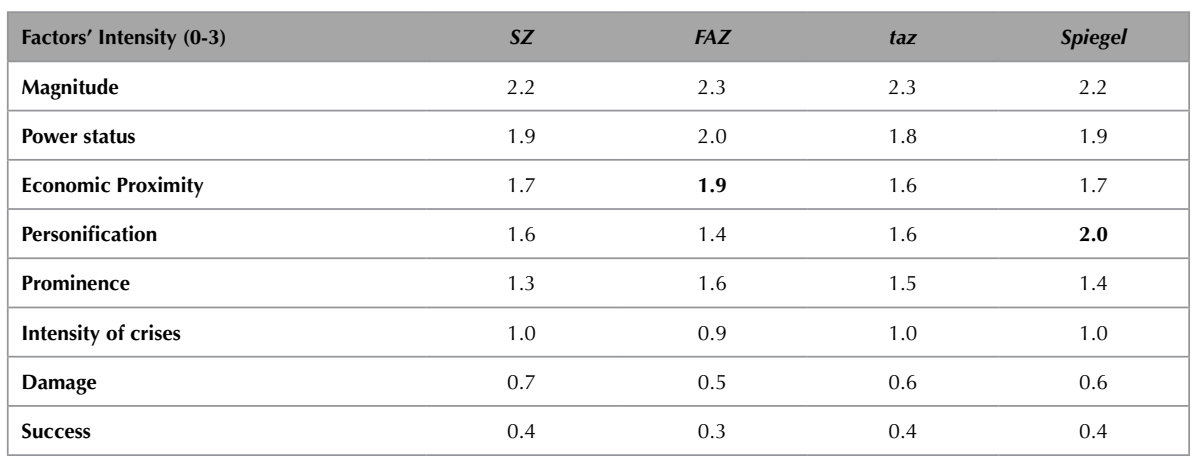

Tab. 4. Average of the intensity level of news factors from 2000-2014

Looking at the intensity of news factors in Table 4, the substantial role of the factor "personification" for Der Spiegel and the "economic proximity" for FAZ is perceptible. 
Concerning the other factors, the variations among media outlets are not significant. In general, and independent of the press organisations, the factors "power status" and "magnitude" play the most significant role for the foreign reporting on Latin America. Countries that boast "power status" or have an intense economic relationship tend to attract more press attention.

Cuba is an exception since the nation received the fourth position among all analysed states regarding press attention, despite the absence of foreign correspondents on the island and the lack of economic proximity to Germany. Brazil, Argentina, and Mexico remained in the first three positions for SZ, FAZ, and taz. On the other hand, Der Spiege/ reports more intensively about Cuba. In the case of $F A Z$, since the newspaper mainly prioritises the factors "power status" and "economic proximity", Cuba gets the sixth ranking position, as seen in Table 5.

\begin{tabular}{|ccccc|}
\hline Rang & SZ & FAZ & taz & Der Spiegel \\
\hline I & Brazil (16.50) & Argentina (19.50) & Brazil (13.60) & Brazil (21.70) \\
\hline II & Argentina (14.60) & Brazil (19.10) & Argentina (12.40) & Cuba (11.40) \\
\hline III & Mexico (10.70) & Mexico (10.90) & Mexico (9.60) & Mexico (9.90) \\
\hline IV & Cuba (8.90) & Venezuela (8.20) & Colombia (9.60) & Colombia (9.10) \\
\hline V & Venezuela (7.20) & Colombia (6.80) & Cuba (8.80) & Venezuela (7.90) \\
\hline VI & Colombia (7.00) & Cuba (6.50) & Venezuela (6.50) \\
\hline
\end{tabular}

Tab. 5. The most-reported countries per press organisations (2000-2014) in per cent

\section{News factors developments over the years}

Long-term analyses have demonstrated that specific news factors can be more or less useful for an extended period, even if they occur with different intensity (WILKE, 1998, p. 48). In his analysis of the constants and changes in foreign reporting, Wilke (ibid.) proves that journalistic predictors, in general, show greater stability, since journalist selection criteria do not regularly change, at least not "from one day to the another" (ibid.). The news choice is based on strongly agreed rules, without huge discrepancies. The research's assumptions here were an increasing concentration of conflicts and controversies in foreign political reporting, an intensification of the news factor "personification" and finally a decline in political coverage as an indicator of "tabloidisation" (MAIER, RUHRMANN, STENGEL 2009). If one first considers the intensity of news factors over 15 years, no clear trends can be observed, as demonstrated in Table 6. The most effective news factors remain "magnitude," followed by "power status," "economic proximity", and "personification." 


\begin{tabular}{|c|c|c|c|c|c|c|c|c|c|c|c|c|c|c|c|}
\hline Intensity & 00 & 01 & 02 & 03 & 04 & 05 & 06 & 07 & 08 & 09 & 10 & 11 & 12 & 13 & 14 \\
\hline Magnitude & 2.2 & 2.3 & 2.4 & 2.3 & 2.2 & 2.1 & 2.2 & 2.3 & 2.4 & 2.4 & 2.3 & 2.2 & 2.1 & 2.2 & 2.4 \\
\hline Economic Proximity & 1.8 & 1.9 & 2.0 & 1.9 & 1.6 & 1.7 & 1.7 & 1.8 & 1.5 & 1.6 & 1.4 & 1.6 & 1.8 & 1.9 & 1.8 \\
\hline Prominence & 1.5 & 1.4 & 1.4 & 1.4 & 1.5 & 1.4 & 1.6 & 1.6 & 1.7 & 1.6 & 1.2 & 1.5 & 1.4 & 1.6 & 1.4 \\
\hline Conflict \& Controversy & 0.6 & 0.8 & 0.9 & 0.8 & 0.8 & 0.6 & 0.5 & 0.8 & 0.8 & 0.8 & 0.6 & 0.7 & 0.67 & 0.7 & 0.8 \\
\hline Damage & 0.3 & 0.7 & 0.7 & 0.6 & 0.6 & 0.5 & 0.4 & 0.6 & 0.6 & 0.6 & 0.9 & 0.6 & 0.5 & 0.5 & 0.6 \\
\hline
\end{tabular}

Tab. 6. Trends in news factors' intensity over the 15 years

From 2008 to 2011, the factor "personification" occupies the third place in the intensity rank, even before "economic proximity," but only with a difference of two decimals digits. The factor has always been a relevant aspect for the press, but its intensity has barely changed over time. Considering now the three aggregated periods of analysis, the average of "personification" intensity within the thematic areas varies from 1.5 (2000-2004) to 1.6 (2005-2009 and 2010-2014), a small growth that does not confirm any specific trends.

\begin{tabular}{|c|c|c|c|c|c|c|c|c|c|c|c|c|c|c|c|}
\hline Factors & 00 & 01 & 02 & 03 & 04 & 05 & 06 & 07 & 08 & 09 & 10 & 11 & 12 & 13 & 14 \\
\hline Magnitude & 95.3 & 96.1 & 97.6 & 96.8 & 96.4 & 95.2 & 95.0 & 96.8 & 97.1 & 97.0 & 98.7 & 98.1 & 94.0 & 98.3 & 97.0 \\
\hline $\begin{array}{l}\text { Personifica- } \\
\text { tion }\end{array}$ & 89.5 & 87.4 & 86.7 & 88.8 & 90.8 & 90.0 & 90.4 & 92.2 & 95.0 & 95.3 & 91.8 & 93.4 & 90.3 & 89.1 & 88.9 \\
\hline $\begin{array}{l}\text { Economic } \\
\text { Proximity }\end{array}$ & 82.6 & 85.9 & 90.9 & 83.6 & 73.3 & 79.7 & 75.8 & 85.8 & 71.8 & 82.4 & 68.3 & 77.5 & 81.5 & 87.8 & 82.9 \\
\hline Eliteness & 85.2 & 83.1 & 84.0 & 81.0 & 83.8 & 81.7 & 84.8 & 81.2 & 86.2 & 81.9 & 76.7 & 79.6 & 79.9 & 80.8 & 81.6 \\
\hline $\begin{array}{l}\text { Conflict \& } \\
\text { Controversy }\end{array}$ & 45.2 & 60.7 & 62.2 & 53.6 & 56.2 & 45.9 & 43.8 & 55.0 & 60.6 & 58.4 & 59.5 & 48.8 & 51.9 & 52.9 & 56.4 \\
\hline $\begin{array}{l}\text { Crisis within } \\
\text { Politics }\end{array}$ & 65.1 & 64.1 & 69.5 & 67.6 & 73.8 & 65.7 & 58.9 & 69.9 & 73.4 & 73.0 & 60.8 & 59.1 & 68.9 & 66.9 & 69.9 \\
\hline Negativity & 38.0 & 51.4 & 57.4 & 41.6 & 44.6 & 39.4 & 33.8 & 39.0 & 44.8 & 44.6 & 46.4 & 40.4 & 36.1 & 36.1 & 42.3 \\
\hline Success & 30.4 & 22.8 & 23.0 & 28.0 & 29.1 & 33.3 & 29.6 & 28.9 & 25.7 & 33.0 & 30.4 & 36.6 & 32.9 & 29.8 & 32.1 \\
\hline
\end{tabular}


Looking at the frequency of factors in each year separately (Table 7), it is not possible to identify any long-term trends either. Concerning the factor "conflict," even though crisis-centrism (more than half of the political coverage on Latin America contains some crisis) played an essential role, no increase has been identified. On the contrary, we found a slight reduction of $3 \mathrm{pp}$ in the factor within the political coverage. The focus on crises is indeed a constant of its political reporting. Overall, "crises" has increased 2pp across all reporting areas, while "negativity" has decreased 6pp. That can be an indicator that despite various crises, positive perspectives of the conflicts such as peace negotiations, dispute resolution, or improvements of a particular state were presented simultaneously.

\section{Conclusions}

Regarding our first question, the most critical news factors for the foreign reporting on Latin America by the German press are "magnitude," followed by "power status," "economic proximity" and "personification." Critical events can modify reporting trends for a short time but are not enough to alter the patterns of intensity and frequency in the long term. The factor "personification" plays a significant role for the magazine Der Spiegel, whereas "economic proximity" appears to be most influential in the financial-oriented FAZ.

Concerning trends over the years, related to our second research question, we confirmed only a certain degree of depoliticisation. We observed a slight loss of importance of "Domestic Policy" (6pp) and "Economy \& Finance" (8pp) in favour of non-political and non-economic thematic areas. Even though $F A Z$ had the smallest reduction, the decrease of "Domestic Policy" was noted across all analysed media outlets. Despite this slight depoliticisation, it is hard to confirm a strong tendency towards tabloidisation concerning the third hypothesis, since other news factors such as "personification," "negativity" or "crises" remain remarkably stable. Although crises and personification are a constant of the news coverage on Latin America, we did not identify any clear increasing trends. These results seem plausible since tabloid journalism does not have a strong tradition in Germany (Esser, 1999, p. 296). Schönbach (2000) demonstrated, for instance, that the adoption of tabloids methods by local German papers did not result in better sales benefits.

The problematic aspect of this pattern of coverage is the relevance given by the press to factors such as "power status" and "economic proximity." In practice, it means that small countries will be reported only in the case of significant and negative events, which can lead to a distorted image. The German press keeps reproducing the power structures within the Latin American continent. Indeed, small countries show a narrow range of topics, and, in some situations, bad press can be a long-term problem, especially if that is the only information available about a specific state (ANHOLT, 2009). Furthermore, it seems plausible that similar results concerning the determinants of Latin America foreign reporting could be found in other European media systems. When considering that international 
news agencies are still the principal agenda-setter of international news coverage, one presumes that several Europeans publications would reproduce the same reporting scheme, despite the presence of foreign correspondents in the continent (BOYD-BARRETT 2010; JOHNSTON \& FORDE 2011; PATERSON 2011). The Spanish press, on the other hand, may display slightly different results due to its cultural proximity to Latin America and stronger immigration flows, but further empirical research is necessary to confirm this assumption (IGARTUA, CHENG \& MUÑIZ, 2005).

Regina Cazzamatta is a PhD candidate at the University of Erfurt, Germany. She received her Master Degree in Media and Communication Studies from the University of Erfurt. In Sao Paulo, she graduated in Communication Studies and had post-graduation in International Journalism from the Pontifical Catholic University of Sao Paolo. Author of the book - 'Brasilien- Berichterstattung in der deutschen Presse'.

regina.cazzamatta@uni-erfurt.de

\section{References}

ANHOLT, S. The media and national image. Place Branding and Public Diplomacy, v. 5, n. 3, p. 169-179, ago. 2009.

AWA. Allensbacher Markt-und Werbeträgeranalyse. [s.l: s.n.].

BOYD-BARRETT, O. National and International News Agencies: Issues of Crisis and Realignment. International Communication Gazette, v. 62, n. 1, p. 5-18, 1 fev. 2000.

News agencies in the turbulent era of the Internet. Barcelona: Generalität de Catalunya, 2010.

BROSIUS, H.-B.; KOSCHEL, F.; HAAS, A. Methoden der empirischen Kommunikationsforschung: eine Einführung. 5. Aufl ed. Wiesbaden: VS, Verl. für Sozialwiss, 2009.

BUNDESAMT. Rangfolge der Handelspartner im Außenhandel der Bundesrepublik Deutschland. Disponível em: <https://www.destatis.de/DE/Publikationen/Thematisch/Aussenhandel/ Gesamtentwicklung/ZusammenfassendeUebersichtenJendgueltig2070100157004.pdf? blob=publicationFile>. Acesso em: 4 maio. 2018.

CAZZAMATTA, R. Brasilien-Berichterstattung in der deutschen Presse. Berlin: Frank \& Timme, 2014a.

. A imagem do Brasil na imprensa alemã — um estudo empírico sobre os fatores de seleção da notícia e da estrutura do noticiário. Estudos em Jornalismo e Mídia, v. 11, n. 2, p. 540, ago. 2014b.

. The determinants of Latin America's news coverage in the German press. The Journal of International Communication, p. 1-22, 3 jul. 2018.

COVARRUBIAS, A.; DOMÍNGEUZ, J. I. Introduction. Latin America in World Politics. In: DOMÍNGUEZ, J. I.; COVARRUBIAS VELASCO, A. (Eds.). Routledge handbook of Latin America in the world. New York: Routledge, 2015. p. 1-24. 
ESSER, F. 'Tabloidization' of News: A Comparative Analysis of Anglo-American and German Press Journalism. European Journal of Communication, v. 14, n. 3, p. 291-324, set. 1999.

GALTUNG, J.; RUGE, M. H. The Structure of Foreign News. The Presentation of the Congo, Cuba, and Cyprus Crises in Four Norwegian Newspapers. Journal of Peace Research, v. 2, n. 1, p. 64-90, mar. 1965.

GÖBEL, B.; BIRLE, P.; SPECHT, J. Wirtschafts-, sozial- und geisteswissenschaftliche Lateinamerikaforschung in Deutschland - Situation und Perspektiven. [s.I.] Ibero-Amerikanisches Institut., 2009.

GRAN, C. S. Tabloidisation of the Norwegian News Media: a Quantitative Analysis of Print and Online Newspaper Platforms. London: [s.n.].

HAFEZ, K. Die politische Dimension der Auslandsberichterstattung. Bd.1. 1. Aufl ed. Baden-Baden: Nomos, 2002. v. 1

HAGEN, L. M. et al. Ländermerkmale als Nachrichtenfaktoren. In: HOLTZ-BACHA, C. (Ed.). Wie die Medien die Welt erschaffen und wie die Menschen darin leben. Opladen: Westdt. Verl, 1998. p. 59-82.

HALLIN, D. C.; MANCINI, P. Comparing Media Systems. In: Comparing media systems: three models of media and politics. Communication, society, and politics. Cambridge ; New York: Cambridge University Press, 2004. p. 21-45.

HARCUP, T.; O'NEILL, D. What is News?: News Values Revisited (again). Journalism Studies, v. 18, n. 12, p. 1470-1488, 2 dez. 2017.

HIIK. Conflict Barometer. Heidelberg Institut for International Conflikt Research. Heidelberg: [s.n.]. Disponível em: <https://hiik.de/konfliktbarometer/bisherige-ausgaben/>. Acesso em: 2 jul. 2015.

HOFFMANN, B.; NOLTE, D. Lateinamerika in der internationalen Politik. Information zur politischen Bildung (bpb), p. 61-71, 2008.

IGARTUA, J. J.; CHENG, L.; MUÑIZ, C. Framing Latin America in the Spanish Press: A Cooled Down Friendship between two Fraternal Lands. Communications, v. 30, n. 3, p. 359-372, jan. 2005.

IVW. Werbeträgerdaten - Presseerzeugnisse. Disponível em: <http://daten.ivw.eu/index. php?menuid=1\&u=\&p=>. Acesso em: 5 abr. 2018.

JOHNSTON, J.; FORDE, S. The Silent Partner: News Agencies and 21st Century News. International Journal of Communication, v. 5, p. 195-214, 2011.

LEFKOWITZ, J. "Tabloidization" or Dual-Convergence: Quoted speech in tabloid and "quality" British newspapers 1970-2010. Journalism Studies, v. 19, n. 3, p. 353-375, 17 fev. 2018.

LIPPMANN, W. Public Opinion. 2. print ed. New Brunswick, N. J., U.S.A:Transaction Publishers, 1998.

LOWENTHAL, A. F.; BARON, H. M. A transformed Latin America in a rapidly changing world. In: DOMÍNGUEZ, J. I.; COVARRUBIAS VELASCO, A. (Eds.). Routledge handbook of Latin America in the world. New York: Routledge, 2015. p. 25-41.

MAIER, M.; RUHRMANN, G.; STENGEL, K. Der Wert von Nachrichten im deutschen Fernsehen. Inhaltsanalyse vonTV-Nachrichten im Jahr 2007. Düsseldorf: Landesanstalt für Medien NordrheinWestfalen, 2009.

NOELLE-NEUMANN, E.; SCHULZ, W.; WILKE, J. Publizistik, Massenkommunikation. Frankfurt am Main: Fischer-Taschenbuch-Verl, 2002. 
NOLTE, D.; HOFFMANN, B. Latin America's New Geopolitical Position and Its Implication for Europe. GIGA Working Papers, 2007.

ÖSTGAARD, E. Factors Influencing the Flow of News. Journal of Peace Research, v. 2, n. 1, p. 39-63, mar. 1965.

PATERSON, C. The international television news agencies: the world from London. New York: Peter Lang, 2011.

PATERSON, C.; SREBERNY, A. (Eds.). International news in the 21st century. Eastleigh, Hants, UK: J. Libbey Pub. for University of Luton Press, 2004.

PEW RESEARCH CENTER. Publics around the world follow national and local news more closely than international. Washington, D.C: [s.n.]. Disponível em: <http://www.pewglobal.org/2018/01/11/ publics-around-the-world-follow-national-and-local-news-more-closely-than-international/>. Acesso em: 19 mar. 2019.

PÜRER, H.; RAABE, J. Presse in Deutschland. Konstanz: UVK Verlagsgesellschaft, 2007.

ROSENGREN, K. E. International News: Intra and Extra Media Data. Acta Sociologica, v. 13, n. 2, p. 96-109, abr. 1970.

International News: Methods, Data and Theory. Journal of Peace Research, v. 11, n. 2, p. 145-156, jun. 1974.

SCHÖNBACH, K. Does Tabloidization Make German Local Newspaper Successful? In: SPARKS, C.; TULLOCH, J. (Eds.). Tabloid tales: global debates over media standards. Lanham, Md.: Rowman \& Littlefield, 2000.

SCHRAMM, W. One Day in the World's Press. Fourteen Great Newspapers on a Day of Crisis. Standford, California: Standford University Press, 1959.

SCHULZ, W. Die Konstruktion von Realität in den Nachrichtenmedien: Analyse der aktuellen Berichterstattung. 1. Aufl ed. Freiburg [Breisgau]; München: Alber, 1976.

SPARKS, C. The Panic over Tabloid News. In: Tabloid tales: global debates over media standards. Lanham, Md.: Rowman \& Littlefield, 2000. p. 1-40.

SREBERNY-MOHAMMADI, A.; GRANT, N. (Eds.). Foreign news in the media: international reporting in 29 countries: final report of the "Foreign Images" study. Paris, France: New York, N.Y: United Nations Educational, Scientific, and Cultural Organization; Unipub [distributor], 1985.

STAAB, J. F. Nachrichtenwert-Theorie: formale Struktur und empirischer Gehalt. Freiburg [im Breisgau]: K. Alber, 1990a.

The Role of News Factors in News Selection: A Theoretical Reconsideration. European Journal of Communication, v. 5, n. 4, p. 423-443, dez. 1990b.

THUSSU, D. K. Media Plenty and the Poverty of News. In: PATERSON, C.; SREBERNY, A. (Eds.). International news in the 21st century. Eastleigh, Hants, UK: J. Libbey Pub. for University of Luton Press, 2004. .

TIELE, A. Nachrichtengeographien der Tagespresse: eine international vergleichende NachrichtenwertStudie. Berlin: Logos, 2010.

WERZ, N. Revolutionmythen zu Lateinamerika. Aus Politik und Zeitgeschichte, v. 41-42, p. 32-40, 2010.

WILKE, J. Konstanten und Veränderungen der Auslandsberichterstattung. In: HOLTZ-BACHA, C. (Ed.). Wie die Medien die Welt erschaffen und wie die Menschen darin leben. Opladen: Westdt. Verl, 1998. p. 9-18. 
WU, H. D. The world's windows to the world: An overview of 44 nations'international news coverage. In: PATERSON, C.; SREBERNY, A. (Eds.). International news in the 21st century. Eastleigh, Hants, UK: J. Libbey Pub. for University of Luton Press, 2004. p. 95-108.

WURFF, R. VAN DER. The impact on the Internet on media contents. In: KÜNG, L.; PICARD, R. G.; TOWSE, R. (Eds.). The internet and the mass media. Los Angeles; London: SAGE, 2008. p. 65-85.

Artigo recebido em 29/09/2019 e aprovado em 03/11/2019. 